\title{
Corporate Social Responsibility - On Aspect of Environmental Protection in Vietnam Today
}

\author{
Dr. Cao Thu Hang \\ Institute of Philosophy, Vietnam Academy of Social Sciences; Email: caohang012001@yahoo.com
}

\begin{abstract}
Doi:10.5901/jesr.2015.v5n3p31
\end{abstract}
\section{Abstract}

Through collecting secondary data by deploying desk review method and collecting primary data by using various qualitative methods including observations and interviews of business owners, workers and consumers, the article argues that the corporate social responsibility in the area of environmental protection is essential. First, the article examines the theoretical framework of social responsibility and environmental protection issues in the social responsibility of enterprises. Second, the article considers the implementation of corporate social responsibility for environmental protection of the businesses in Vietnam through the statistics. The article also points out the causes and consequences of this situation. Finally, the article provides some key solutions to make the implementation of environmental policies more effective in reality.

Keywords: environment, enterprise, corporate social responsibility, pollution, Vietnam.

\section{Introduction}

Since 1986 Vietnam has been practicing the Renovation policy and in 2007 Vietnam entered into WTO. Those processes have created opportunities for the development of the country in general and enterprises in particular. However, those processes have also posed many challenges and problems for Vietnam, such as the problems relating to labor, sustainable development, environment protection... As integrated parts of the society, Vietnamese enterprises also hold responsible in dealing with those challenges and problems. And this is corporate social responsibility of which include many contents, such as child labor, discrimination, environment protection...The author of the article only focus on one aspect in the implementation of corporate social responsibility: the corporate social responsibility in the area of environment protection which include some issues like the awareness of corporate social responsibility, report and the compliance of social responsibility of enterprises in the area of environment protection, the issues of production technology, waste disposal...

\section{Research Methodology}

There are two main methods used in this article. The first method is desk review. There are several core reasons that this method is used. First, it is deployed to identify the well-researched areas and their achievements in order to select the exact the less-researched areas that needs to be examined further by this paper. In addition, desk-review of available theories on social responsibility by international and Vietnamese scholars is to help to reconstruct what has been achieved in the field to develop more suitable theoretical framework to be applied in this paper. Third, the method is used to make use of suitable and available secondary data including the materials, information, and statistics of other studies to strengthen supportive argumentations for this paper.

The second one is qualitative method to collect primary data. During the field trips, researchers have deployed method of observation and in-depth interviews with various stakeholders who are business owners, workers and consumers to determine the current status, barriers, and challenges in implementing corporate social responsibility on aspect of environmental protection in Vietnam today. The author conducted in-depth interviews with 50 people, including 15 leaders / entrepreneurs, 15 employees and 20 consumers. Primary data is the strongest evidence to support theoretical frameworks deployed in the paper. 


\begin{tabular}{|l|c|c|c|c|}
\hline & Total members interviewed & Women & Man & Age \\
\hline Leaders/entrepreneurs & 15 & 5 & 10 & $35-55$ \\
\hline Employees & 15 & 8 & 7 & $25-55$ \\
\hline Consumers & 20 & 10 & 10 & $25-55$ \\
\hline
\end{tabular}

\section{Literature Review}

Corporate social responsibility topic, especially in the area of environmental protection was concerned and researched by many scholars in Vietnam and over the world. However, this article just mentions some recent basic works in Vietnam.

The work "Corporate social responsibility in the context of Vietnam join WTO and international economic integration" of the author Ha, L.Th. (2009) includes some basic contents: Firstly, referring to the content of social responsibility in enterprises. According to the author, it is child labor; forced labor; safety, health; freedom of association and collective labor agreements; discrimination; labor discipline; hours of work; salary; prohibit all forms of harassment and abuse; environmental protection; compliance with regulations on tariffs; security; management system. The second content of the book analyzes some basic characteristics of some popular $\mathrm{CoC}$ (Codes of Conduct) and compatibility level of the CoC for Vietnam law, as the SA 8000, WRAP, ISO 9000, ISO 14000, OHSAS 18001, HACCP, GMP. The third content of the book analyzes the situation and proposes official measures to promote the implementation of the social responsibility of enterprises. Those solutions include overcoming technical and trade barriers; establishing an information system that tracks, analyzes and provides the requirements of foreign partners for domestic enterprises; businesses should establish a good efficiency system of governance which minimizes investment costs to implement social responsibility, etc... From the perspective of enterprise's management, the implementation of the social responsibility of enterprises in the area of environment protection, according to the authors means that businesses must be aware of environmental protection in the place of production and business activities. This point is deployed by the author through the three following criteria: first, enterprises themselves should evaluate their negative impacts on the enviroment; second, the issue of recording and keeping records of enterprise's impacts on the environment and third, enterprise's commimment on reduction of negative impacts on the enviroment (Ha, L.Th., p.110).

From an economic approach, in her paper "Enviromental pollution - the social responsibility of Vietnamese enterprises" Tuyet, Ph.T (2012) has outlines the concept of corporate social responsibility; analyzes the benefits of enterprises when they implement corporate social responsibility as well as the issue of environmental pollution in Vietnam today. The aspect of enviroment protection of enterprises when they implement corporate social responsibility has been clarifed by the author in following three contents: awareness, production technology and waste disposal.

From the perspective of sustainable development, in the article "Corporate social responsibility in Vietnam: some imperative theoretical issues and practical", Duc.Ph.V (2009) said that the implementation of corporate social responsibility in Vietnam today not only helps businesses improve sales, their profit, but also makes business sustainability, involves ensuring healthy environment. That sustainability is the condition for the sustainable development of Vietnam - a goal that Vietnam is aiming for. According to the author, the corporate social responsibility is a relatively new issue with Vietnam. However, in recent years, in front of environmental disasters and the negative consequences on society caused by enterprises, the issue of corporate social responsibility on aspect of environmental protection is an urgency requirement, in line with the strategic objectives of sustainable development. To implement corporate social responsibility in Vietnam, the writers have said that propagandizing and educating social responsibility and perfecting the legal framework are urgently needed jobs.

The work "Corporate social responsibility in conditions of market economy" (Co-editor: Duc, Ph.V; Sayer.J; Toan, D.H; Hoa, N.D; Dornberg,U.; 2010) consists of 3 parts. The first part analyzes social responsibility in conditions of market economy - common problems. In this article, the authors suggest that any individual, organization, or community living within society, should also have their responsibility to the community and society. For businesses, it does so, to guarantee the survival and development of enterprises. In the second part, the authors analyze and clarify the social responsibilities of the state, businesses, entrepreneurs and social - political organizations in the conditions of the market economy. Many issues of corporate social responsibility are also clarified in some contents, as businesses must implement environmental issues, employees and customers. The authors also note that, in the implementation of social responsibility, the state, the social - political organizations also have an important role in improving the corporate social responsibility, particularly in Vietnam today. The third part of the work refers to social responsibility in several areas of economic, social, cultural and environmental... This is a collective work of authors, therefore, the aspect of environment protection in the implementation of corporate social responsibility is approached from different angles. Some authors 
approach from the angle of epistemology on the relation between man and nature, and the relation between man and man; others consider from the angle of environmental ethics or some others from the angle of bussiness ethics ( pp. 304348).

From the perspective of management, Doanh, L.D (2009) in the article "Some issues of corporate social responsibility in Vietnam today" said that social responsibility in Vietnam was at the first step of awareness and implementation. Certainly, with the development of the country, that responsibility will be enhanced more with the completion of the legal framework, the state apparatus and institutions of market economy and social civil institutions.

\section{The Theoretical Framework on Corporate Social Responsibility and Corporate Social Responsibility - on Aspect of Environmental Protection}

In recent years, the corporate social responsibility is the focus of many researches. According to the traditional view, businesses should only care about their benefits, profits, and other social issues are unnecessary. However, with time, some enterprises themselves also noticed that, besides the importance of seeking immediate profits, the implementation of a certain number of "out of business" jobs can also bring long term profits for themselves. Moreover, we can see that the society is a tightly linked system; the social aspects are related, interrelated with each other, and closely related to the economic sphere. In contrast, economic activity, as a basic activity of the society, has much impact on other areas of human life, such as natural resources, health workers, occupational safety, food hygiene... That means, in their business operations, businesses have relationship, involving the government, consumers, distributors, investors, competitors competitive, non-governmental organizations, community... Therefore, the corporate social responsibility get the attention of numerous sectors of society, from businesses themselves, to local community, the organizations in civil society, government, etc...

The conception of the World Bank is that the corporate social responsibility is the commitment of business to contribute to sustainable development in cooperation with employees, their families, communities and society in general to improve the quality of life for them, in order to be good for business, useful for development ${ }^{1}$.

The conception of Ha, L.Th. (2009: p.10): "Social responsibility is self-commitment of the business through the development and implementation of systems of management regulations, by the appropriate, publicity and transparency management methods, on the basis of compliance with current legislation; implementing behavior in the conduct of labor relations to harmony combine benefit of businesses, employees, customers, community, society, consumers to reach the sustainable development goals"2.

Author Doanh, L.D. (2009: p.30) said that social responsibility is considered a category of business ethics, related to all business activities of enterprises. According to this "Corporate Social Responsibility can be defined succinctly as a commitment of the enterprises in the conduct consistent with the interests of society in the activities related to interests of customers, suppliers, employees, shareholders, communities and the environment"3.

Thus, in general, all authors agreed that, corporate social responsibility is a commitment to ensure that the interests of the partners involved in the process of production and business activities of enterprises. It covers many topics, such as child labor, environmental protection, anti-discrimination, working time, wages, guarantee human rights, security policy, comply with the law, freedom association and collective agreement...

The environmental protection of the enterprise is one aspect of corporate social responsibility. The paper only concentrates this aspect.

As we have mentioned in the above literature review, in Vietnam corporate social responsibility in the area of environment protection has been viewed by different authors from various angles and with different criteria. Some authors consider it under the angles of three criteria and focused mainly on epistemological factors ( Ha, L.Th, 2009); other authors read it with the angle of the criteria of awareness, production technology, waste disposal (Tuyet, Ph.T, 2012), ect....From the results of previous researches of scholars and from the practice of enterprises in Vietnam, the content of the environmental protection of the enterprise (in this article, I referred to the policy of the business environment), in view of the author, involves primarily (1) the standard of organization focusing on environmental management systems, business awareness, reports, corporate compliance, taxes...; and (2) the standards on

\footnotetext{
${ }^{1} \mathrm{Ni} \mathrm{Gel}$ Twose (2002). Speech at the National Conference on Social Responsibility of the business and national competitiveness, Hanoi, $16-17 / 12 / 2002$.

${ }^{2} \mathrm{Ha}$, L.Th (2009). Corporate social responsibility in the context of Vietnam joining WTO and international economic integration. Science and Technology Publishing, Hanoi, p.10

${ }^{3}$ Doanh, L.D (2009). Some issues about the CSR in Vietnam. Journal of Philosophy, No. 3, 2009, p.30
} 
environmental aspects of products, such as raw materials, production technologies, waste...

\section{Environmental Policy Implementation of Vietnamese Enterprises Today}

According to the survey, in 2012, the number of Vietnamese enterprises is 541,103 ; including state enterprises are 4,715; non-state enterprises are 524,076 and foreign investment enterprises are 12,312 4 .

The number of state enterprises on 01/01/20125.

\begin{tabular}{|c|c|c|c|c|}
\hline \multirow{2}{*}{} & \multirow{2}{*}{ Total amount of enterprises } & \multicolumn{2}{|c|}{ Separate } \\
\cline { 3 - 5 } & & State enterprises & Non-state enterprises & Foreign investment enterprises \\
\hline C & 1 & 2 & 3 & 4 \\
\hline Nationwide (total) & $\mathbf{5 4 1 , 1 0 3 3}$ & $\mathbf{4 , 7 1 5}$ & $\mathbf{5 2 4 , 0 7 6}$ & $\mathbf{1 2 , 3 1 2}$ \\
\hline
\end{tabular}

To this day, the number of enterprises still growing, as of 2015, the estimated total number of Vietnamese enterprises is about 600,000 . Along with the deeper integration of the country, the Vietnameses enterprises are growing, with many relations with not only domestic, but also foreign partners. Vietnamese enterprises are well aware that, during the seek for profits, they should be mindful of the interests of the community, customers, employees... This process inevitably arises to social responsibility implementing, so as to enhance their competitiveness. The implementation of the social responsibility in the area of environmental protection also helps Vietnam to attract more labor forces with labor-friendly environment as well as more consumer customers with eco-friendly products, clean technologies...

The implementation of social responsibility in general, socially responsible in the area of environment protection in particular can not only show increasingly awareness of Vietnamese enterprises, but also profit them. With such awareness, Vietnamese enterprises have also gained certain achievements in the implementation of proper environmental policy, through which environmental issues in Vietnam are improved somewhat. However, besides that, the implementation of environmental policies of Vietnamese enterprises has certain negative aspect.

The negative aspects in implementing environmental policies of Vietnamese enterprises include 2 criteria as mentioned above. However, due to the framework of this article, the environmental policies of the businesses have been explored in some basic indicators: awareness, reports on the environmental impact, proclaiming environmental standards where manufacturing, production technology and waste.

\subsection{Awareness of enterprises on environmental protection issues}

Awareness is the first important step in implementing environmental policies of the enterprises. Right understanding will lead to proper activities. Enterprises should aware of the importance of environmental policies to the development of them, to the protection of their habitats and their own community, then they make the effective actions to improve the results of their environmental policies. Conversely, if there is no proper awareness of the importance of environmental policies for production and business activities, with the environment, any external effects as requirement to build the environmental impact reports, technological changes... is only superficial and therefore, will not be effective.

In Vietnam, the business owner has proper awareness on environmental issues and environmental protection. When asked, they say that they are aware of the importance of the environment and environmental protection in their production and business activities. For example, in a In-dept interview (IDI) an export business owners, Mr Tran Van Quang, 52 years old, says that his enterprise is always conscious of environmental protection, because this is the factor that should be implement since the enterprise engaged in the business accordingly with the law, with the requirements of his partners.

For employees, the investigation in the textile industry shows that $15.9 \%$ very concerned, $64 \%$ interested in the environment and environmental protection; $15.1 \%$ of surveyed employees was interested and $5 \%$ was not interested.

Assessing the impact of manufacturing activities of enterprises on the environment, $15.4 \%$ of employees did not know, did not care about this issue.

\footnotetext{
4 Source: General Statistics Office of Vietnam (2012), Report on results of the review in 2012 the number of enterprises.

${ }^{5}$ That is the number of enterprises officially registered, not to mention the small and households business (unregistered business) accounted for a greater number of officially registered figure. This is typical of Vietnam, therefore, the article surveys both registered and small and householders businesses; call all of them "enterprise".
} 
Employees also said that activities conducted in environmental protection by businesses are basically: monitoring the implementation of regulatory standards for environmental protection in manufacturing $(59.3 \%$ confirmed); propagandizing the environmental protection to employees (44.3\%); renovating landscape/planting trees (35.7\%); but operations with application of clean/friendly technologies, using cleaner energy, investment in waste disposal or construction the waste management regulations was not been appreciated by the worker because they were at low and relatively low proportion 6 .

\subsection{Environmental protection activities of enterprises (employees interview) ${ }^{7}$}

\begin{tabular}{|l|c|c|c|}
\hline & Yes & No & No idea \\
\hline Implementation of standards / regulations on environmental protection in production & $59.3 \%$ & $36.1 \%$ & $4.6 \%$ \\
\hline Applying clean/environmentally friendly technologies & $13.5 \%$ & $78.0 \%$ & $8.5 \%$ \\
\hline Using clean materials & $9.3 \%$ & $82.0 \%$ & $8.7 \%$ \\
\hline Investing in waste disposal & $18.1 \%$ & $73.1 \%$ & $8.7 \%$ \\
\hline Construction the waste management regulations & $13.1 \%$ & $78.9 \%$ & $8.0 \%$ \\
\hline Propagandizing to employees about environmental protection & $44.3 \%$ & $51.7 \%$ & $4.1 \%$ \\
\hline Propagandizing to community about environmental protection & $15.4 \%$ & $80.6 \%$ & $4.1 \%$ \\
\hline Reinovating landscape, planting trees & $35.7 \%$ & $60.0 \%$ & $4.3 \%$ \\
\hline No action & $26.3 \%$ & $66.2 \%$ & $7.5 \%$ \\
\hline
\end{tabular}

Thus, business owners and employees have relatively proper awareness on environmental issues and environmental protection, but these perceptions may just stop at observance of the provisions of law and partners in business relations of production. This is demonstrated through the lack of implementation of other content in the environmental policies of the enterprise (as mention below), such as implementation of the environmental impact, using technology, waste disposal reports. There is a gap between awareness and action so there may be aware but for many reasons, no action.

\subsection{Environmental impact reports}

One of the requirements for registration of production activities of Vietnamese enterprises is the assessment of the environmental impact by their activities. It includes determining, predicting, assessing the impact of business production activities to the environment. Accordingly, all factors related to the environment are made right from the outset of production activities, during the implementation process and continued throughout the operation of the businesses.

However, this has not been clearly defined by businesses. The reports on the environmental impact of production activities of enterprises are mainly superficial, or doing just to meet the requirement when registering business production. This can be seen through some industrial zones in Vietnam, where the standards relating to the environment, to registering the production and business of enterprises are very strict regulated ${ }^{8}$. Investigations in 27 industrial zones Mekong Delta shows that, up to $25 / 27$ industrial zones have violations such as no report of environmental impact assessment; no making report of added environmental impact assessment; no construction of environmental treatment facilities and incompletely implementing the content of a report on environmental impact. Some project investors have not fully complied with the contents of the approved decisions by the authorities on environmental protection; reports on environmental impact assessment are still on ${ }^{9}$.

The enterprises in industrial zones have such a situation, for sure with producers of small business, the environmental impact reports do not seem to get their attention. When asked whether planning for environmental policies or not when initiating of production and manufacturing, Nguyen Van Thanh, 54 years old, owner of a brick manufacturing facility said that, he did not know that is required to report environmental impacts and no plans for this. He only worries how to produce and consume his commodities.

\footnotetext{
${ }^{6}$ Source: The survey of Institute of Philosophy, Vietnam Academy of Social Sciences (VASS), 2012.

${ }^{7}$ Source: The survey of Institute of Philosophy, VASS, 2012.

8 Until early July 2014, Vietnam has 300 industrial parks. In Vietnam, when registration, the business must comply with the provisions of the law, the decree of the government in the field of environmental protection, such as the Law on Enterprises, the Law on Environmental Protection, Decree No. 29/2011 / ND-CP of the Government dated 18.04.2011 provisions on strategic environmental assessment, environmental impact assessment, environmental protection commitments, etc.

${ }^{9}$ Source: Thanh Huy: Mekong Delta: Environmental pollution in industrial areas (Đồng bằng sông Cửu Long: Ô nhiễm môi trường ở các khu công nghiệp), http://www.kcn.soctrang.gov.vn, date 16/1/2014.
} 
An important element in the environmental impact reports of the business is proclaiming environmental standards of the producers, as standards of smoke, dust... for all of the business can check and compare. This is imperative for the business. However, this issue has not been 100\% interested by businesses. Investigations at the premises of textile shows that, $83 \%$ of leaders said that their companies proclaim the environmental standards at the factory, $17 \%$ admitted that their businesses did not proclaim environmental standards at the factory.

Another part of the environmental impact reports of the businesses is the environmental management in enterprises. This requires an compliance assessment and officers. This work is important, because through it, the result of environment managing of enterprises is improving. However, this work has not been interested by businesses. Survey shows that only $64.4 \%$ leader of respondents said their companies have environmental dedicated staff, $35.5 \%$ said their companies do not have dedicated staff but only part-time staff ${ }^{10}$.

\subsection{The use of production technology}

Manufacturing technology is one of important elements in protecting the environment. Basically, the old production technology, during operation, often causes compounds that generate more negative impact on the environment than new technologies. For example, in the construction sector, if production technology brick kiln, furnace hopman (old technology) will burn the charcoal from $180-220 \mathrm{~kg}$ of coal and burn the land from 1.8 to $2.2 \mathrm{~m} 3 \mathrm{dust} / 1000$ standard bricks. Meanwhile, if manufacturing bricks with tunnel kiln technology (new technology in the production of bricks), the average of $120-150 \mathrm{~kg}$ of coal consumption and $1.2-1.5 \mathrm{m3} / 1000$ standard bricks. Therefore, within 1 product unit, the volume of waste causing environmental pollution of the artisan-style brick kiln, furnace, oven hopman is about 1.5 times larger than the tunnel brick factories.

Many actual figures proved emissions of manual brick kilns, brick kilns vertical, hop-man type damage to crops and the health of communities around ${ }^{11}$.

In a developing country such as Vietnam, most Vietnamese enterprises are using obsolete technology in compare with the world. That makes the use/consumption of natural resources, energy increase with higher waste that led to resources being exploited more and increased environmental pollution. Sociological investigations showed that most domestic companies are using the technology is lagging behind the average level of the world. Level of outdated equipment and very outdated equipment account for $52 \%$, while the level of modern equipment is only $10 \%$ and the level of medium devices is $38 \%$. Notably, in the area of small production equipment which is at backward and very backward is up to $70 \%$... The majority of businesses use the technology of the 80 s of the last century; ... some qualified staff is around $7 \% 12$.

Referring to the old technology, we have to mention the millions of small business producers, particularly existing in the villages in Vietnam. As reported, there are about 1300 craft villages in Vietnam today. The development of craft villages in Vietnam has created millions of jobs, solved the economic life of many households. However, in the villages, the majority of households/businesses with production space is interwoven in the neighborhood or at home, makeshift factories, cramped, not ensuring the work environment. In these craft villages, outdated or simple technology; machinery and equipment used mostly old type, or self-made; the use of modern technology, or applying scientific and technical progress are very limited. All those problems are not only consuming more energy production, but also creating untreated environmental pollution as smoke, dust, toxic chemicals.....

\subsection{Waste disposal}

According to the current regulations in Vietnam, the facility/enterprise production and business activities are subject to strict quality criteria for the protection of the environment, such as solid waste handling, water... before being discharged into the surrounding environment; the level of dust is right at the threshold of the permitted standards. However, in reality, many businesses still have not been properly treated as statutory and commitment. In some enterprises, the stuff is not filtered, the wastes are not untreated but discharged directly into the environment. One research indicated that more than

\footnotetext{
${ }^{10}$ Source: The survey of Institute of Philosophy, VASS, 2012.

${ }^{11 S o u r c e: ~ E n v i r o n m e n t a l ~ p r o t e c t i o n ~ a n d ~ m a n a g e m e n t ~ o f ~ t h e ~ c o n s t r u c t i o n ~ i n d u s t r y, ~ J o u r n a l ~ C o n s t r u c t i o n, ~ N o . ~ 6, ~} 2009$ (Quản lý bảo vệ môi trường của ngành xây dựng, Tạp chí Xây dựng, số 6, 2009). http://moitruong.xaydung.gov.vn/moitruong/module/news/view content.asp?|D=1190\&/angid=1

$1252 \%$ of enterprises use outdated technology. Electric Newspaper Industry and Trade (52\% doanh nghiệp sử dụng công nghệ lạc hậu; Báo Công thương online): http://baocongthuong.com.vn/52-doanh-nghiep-su-dung-cong-nghe-lac-hau.html; date 14/05/2015.
} 
$60 \%$ of one million $\mathrm{m} 3$ of wastewater per day from the industrial park is discharged into the environment untreated 13 .

As for the textile industry, paper and pulp industry, levels of wastewater containing cyanide (CN-) and NH3 reached to 84 times the permissible standards. In 2012, industrial zones Tham Luong (Ho Chi Minh City, Vietnam) discharged to $500.000 \mathrm{~m} 3$ per day 14 .

Mekong Delta is home for industrial parks and export processing zones to grow rapidly, but has been facing the negative environmental impacts from the operation of industrial parks, industrial clusters, as pollution of water, air and solid waste ... According to the investigation, in the Mekong Delta provinces, businesses in the industrial zones, industrial complexes discharged directly into the environment 47 million liters of waste water and 220,000 tons solid waste each year... Among them, there approximately be 75\% industrial zones and $85 \%$ industrial cluster in Mekong Delta that has no sewage system focus, or yes but does not meet the prescribed standards ${ }^{15}$.

In the craft villages, where concentrating a lot of small business households, the situation was somewhat more severe. Not only the chemical waste water is discharged directly into the lake, but the garbage of households that still poured indiscriminately into the environment where people live. In those craft villages, there almost is no processing systems and sorting garbage, sewage.

It can be seen that the above things is one of the causes of environmental pollution worsening of Vietnam. Some environmental experts said that Vietnam is one of countries that is facing many challenges related to pollution and environmental degradation threatened to the health of the community residence. Accordingly, Vietnam is in the top 10 countries with heavy air pollution ${ }^{16}$. Along with that, according to a research, groundwater resources of Vietnam are facing problems on a large scale salinisation and pollution of microbiological and heavy metal pollution seriously... Many places have detected signs brand coliform contamination exceeds permitted standards from hundreds to thousands of times. Pollution of phosphate (P-PO4) also tend to increase over time ${ }^{17}$.

The cause of these problems is due to Vietnam enterprises are mostly small and medium enterprises (95\%), low economic potential. Mrs. Nguyen Thi Lan, 45 years old, a pottery production master, said that her business also want to invest a system of modern production lines, clean, environmentally friendly, but because of large investment funds, her enterprise is still not accessible. Besides, employees, consumers, the community is not aware of all the importance of implementing corporate social responsibility, considering it is the job of the business. Le Van Minh, a consumer, 38 years odd, said that he is only paying attention to the use of the product, but rarely pay attention to products whether they are friendly with environment, can be recycled or not. He still using plastic bags for containing food and other items, but rarely use paper bags, because of the convenience. Finally, we can see, the access to the contents of the implementation of social responsibility, environmental policy of the enterprise is limited.

One another reason is that the legislation relating to environmental protection by enterprises still has many gaps. Vietnam has Environment Protection Law. Besides, there are other related decrees of corporate responsibility in environmental protection. However, documents are or outdated, or overlapping, or the provisions on sanctions related to the environmental field are not sufficient to deter violations enterprises. Typically, the Vedan Company discharged untreated waste into the environment for over 10 years, makes heavily polluted to the Thi Vai and Dong Nai Rivers, beside wastewater charges, this company is just punished only 300 million VND (almost 15,000 dollars) for this behavior. This is too mild penalties for such a behavior.

\section{Some Solutions}

With those above-mentioned problems, it can be said that, enhancing social responsibility in the area of environmental protection of the Vietnam businesses is now essential. That should be done with the involvement of all concerned parties. That is:

(13) Lê Hạnh Nguyên. Vietnam faces challenges of environmental pollution caused by man-made (Việt Nam đối mặt thách thức ô nhiễm môi trường do con người tạo ra), date 05/06/2013. http://www.baomoi.com/Viet-Nam-doi-mat-thach-thuc-o-nhiem-moi-truong-do-connguoi-tao-ra/144/11184229.epi.

(14)Khanh Vy. Vietnam groundwater resources are serious pollution (Nguồn nước ngầm ở Việt Nam ô nhiễm nghiêm trọng). http://www.cand.com.vn/vi-VN/khcn/2013/5/199426.cand, date 21/05/2013.

${ }^{15}$ Source: Thanh Huy: Mekong Delta: Environmental pollution in industrial areas (Đồng bằng sông Cửu Long: Ô nhiễm môi trường ở các khu công nghiệp) http://www.kcn.soctrang.gov.vn/, date 16/01/2014.

${ }^{16}$ Hung Vo. Vietnam is under the top 10 of heavy air pollution countries (Việt Nam thuộc top 10 nước ô nhiễm không khi nặng).

http://www.vietnamplus.vn/viet-nam-nam-trong-10-nuoc-o-nhiem-khong-khi-nang/221092.vnp; date 18/09/13.

${ }^{17}$ Khanh Vy. Vietnam groundwater resources are serious pollution (Nguồn nước ngầm ở Việt Nam ô nhiễm nghiêm trọng). http://www.cand.com.vn/vi-VN/khcn/2013/5/199426.cand , date 21/05/2013. 
Firstly, the Government

- to fund supporting to businesses through key programs, national projects, preferential credits, tax, training environmental experts, support businesses in implementing policies environment.

- $\quad$ to have a clear mechanism of reward and punishment mechanism for businesses which have serious frauds in the implementation of social responsibility in the field of environmental protection.

- to develop mechanisms and policies to attract the participation of stakeholders, partners and organizations in the process of promoting social responsibility of enterprises in environmental protection ${ }^{18}$.

Secondly, consumers

Consumers should use the products of the enterprises which meet environmental standards, boycott and do not use the product of the business that has done violation of the contents of environmental protection. Must weigh the immediate benefits and long term benefits between the use of product/service that is less impact on the environment but may have a higher price than the products/services produced by outdated technology that makes environmental pollution.

Thirdly, employees

- Need to raise awareness about the environment, the impact of production activities of the enterprise on the environment, so that, giving appropriate measures to minimize the impacts.

Fourthly, the business itself

- Search for financial aid, the support of the government, associations, professional organizations to promote the implementation of social responsibility, environmental policies in their businesses better.

- Train management team, highly qualified staff in order to facilitate access to the skills and qualifications of modern management.

- Develop dialogue mechanisms, share information with stakeholders, such as employees, investors, communities, governments ... Together, there are the sharing and learning of businesses domestically and internationally.

\section{Conclusion}

With all above mentioned issues we can see that many enterprises in Vietnam today are aware of the importance of the implementation of social responsibility in the area of environment protection. However, due to many reasons, such as limited finances, the backwardness of some legal documents related to social responsibility in the area of environment protection..., the implementation of social responsibility in the area of environment protection of Vietnamese enterprises is limited: besides successes there still exist certain limitations. And this is one of the cause of the environmental pollution in Vietnam today. In order to deal with such situation, there needs a comprehensive solution with the involvement of different actors. Because in the development of modern society, the social sectors have closely related to each other. Thus, although "social responsibility of business" and the characteristics of Vietnam today, the issue, in our view, is not only belong to the Vietnamese businesses themselves, but also the problem of all employees, investors, the community and society... Therefore, improving the Vietnamese corporate social responsibility needs the participation and efforts of everyone.

\footnotetext{
${ }^{18}$ Currently, besides the support of the government in promoting implementation of social responsibility of business, there are many other organizations also sponsored Vietnamese enterprises to implement these issues, such as the project "Support to Small and Medium Enterprises of Vietnam to improve understanding and implementation of social responsibility of enterprises to strengthen links with global supply chains in sustainable food producing "by the European Union (EU) finance Support, United Nations Industrial Development Organization (UNIDO) implemented. UNIDO Representative in Vietnam, Mr. Patrick J. Gilabert said, the majority of enterprises in Vietnam are small and medium-sized enterprises; the capacity has not met the requirements for Social Responsibility of Business. He also adds: "UNIDO is supporting technology to project activities to promote environmental and social aspects of small and medium-sized enterprises of Vietnam, strengthen the integration of such businesses global supply chain through increased awareness, understanding and implementing social responsibility of enterprises in all three main aspects: production of environmentally appropriate, improved labor practices and enhance international competitiveness".
}

Source: http://sokhdt.thainguyen.gov.vn/Default.asp?id_DB=268201194152\&strContent=8\&strShow=20 


\section{References}

Corporate social responsibility in conditions of market economy (2010) (Co-editor: Duc, Ph.V; Sayer.J; Toan, D.H; Hoa, N.D; Dornberg,U.). Social Sciences Publishing House.

Doanh, L.D. (2009). Some issues about the CSR in Vietnam. Journal of Philosophy, No. 3.

Duc, Ph.V (2009) "Corporate social responsibility in Vietnam: some imperative theoretical issues and practical", Journal of Philosophy, No. 3.

Environmental protection and management of the construction industry, Journal of Construction, No. 6, 2009 (Quản lý bảo vệ môi trường của ngành xây dựng) http://moitruong.xaydung.gov.vn/moitruong/module/news/viewcontent.asp?ID=1190\&langid=1

General Statistics Office of Vietnam (2012), Report on results of the review in 2012 the number of enterprises.

Ha, L.Th. (2009). Corporate social responsibility in the context of Vietnam joining WTO and international economic integration. Science and Technology Publishing, Hanoi.

Hung Vo. Vietnam is under the top 10 of heavy air pollution countries (Việt Nam thuộc top 10 nước ô nhiễm không khí nặng). http://www.vietnamplus.vn/viet-nam-nam-trong-10-nuoc-o-nhiem-khong-khi-nang/221092.vnp; date 18/09/13.

Khanh Vy. Vietnam groundwater resources are serious pollution (Nguồn nước ngầm ở Việt Nam ô nhiễm nghiêm trọng) http://www.cand.com.vn/vi-VN/khcn/2013/5/199426.cand, date 21/05/2013.

Law on Enterprises, Law on Environmental Protection, Vietnam

Lê Hạnh Nguyên. Vietnam faces challenges of environmental pollution caused by man-made (Việt Nam đối mặt thách thức ô nhiễm môi trường do con người tạo ra), date 05/06/2013. http://www.baomoi.com/Viet-Nam-doi-mat-thach-thuc-o-nhiem-moi-truongdo-con-nguoi-tao-ra/144/11184229.epi

Thanh Huy: Mekong Delta: Environmental pollution in industrial areas, http://www.kcn.soctrang.gov.vn/ (Đồng bằng sông Cửu Long: Ô nhiễm môi trường ở các khu công nghiệp), date 16/01/2014.

The survey of Institute of Philosophy, VASS, 2012.

Tuyet, Ph.T (2012), "Enviromental pollution- the social responsibility of Vietnamese enterprises", Banking Science \& Training Review, No 120.

$52 \%$ of enterprises use outdated technology. Electric Newspaper Industry and Trade (52\% doanh nghiệp sử dụng công nghệ lạc hậu; Báo Công thương online): http://baocongthuong.com.vn/52-doanh-nghiep-su-dung-cong-nghe-lac-hau.html; date 14/05/2015. 
